\title{
1 A Case for Chemical Weathering in Soils of Hurd Peninsula, Livingston Island, South
}

\section{Shetland Islands, Antarctica}

4 Nicholas W. Haus ${ }^{1}$, Kelly R. Wilhelm ${ }^{1 *}$, James G. Bockheim ${ }^{1}$, John Fournelle ${ }^{2}$ and Michael

5 Miller $^{2}$

6

$7 \quad{ }^{1}$ Department of Soil Science, University of Wisconsin, Madison, WI

$8 \quad{ }^{2}$ Department of Geoscience, University of Wisconsin, Madison, WI

\section{Abstract}

11 The soils of the South Shetland Islands, Antarctica are considered weakly developed. Chemical

12 weathering processes are generally considered to be negligible except in areas that receive large

13 additions of seabird guano. In this paper we describe and analyze 19 soils on Hurd Peninsula,

14 Livingston Island in the South Shetland Island Archipelago. The soils were classified according

15 to US Soil Taxonomy and were generally weakly developed Gelorthents, Humigelepts and

16 Haplorthels. However, B horizon formation, rubification and increases in extractable iron and

17 aluminum were observed on toposequences of raised beaches. The deposition of tephra and/or

18 guano are likely responsible for the chemically driven processes. Guano deposits contain

19 phosphates and oxalic acid, causing phosphatization and/or dissolution of silicates. Input of

20 tephra with easily weatherable minerals may account for metastable mineral formation. Tephra

21 deposition in the oldest raised beaches has formed a fine-textured mantle overlying the coarser

22 textured subsoils. Highly weatherable tephra, as opposed to guano deposition, appears to

23 influence soil formation at Hurd Peninsula. 
25 Key words: Antarctic Soils, Entisols, Tephra, Ornithogenic Soils, Soil Weathering

26

$27 *$ Correspondence to: K. Wilhelm, University of Wisconsin-Madison, Department of Soil

28 Science, 1525 Observatory Dr., Madison, Wisconsin, 53706, USA.

29 E-mail: krwilhelm@wisc.edu

30 


\section{Introduction}

32 The main processes driving soil formation in the South Shetland Islands have been cited as

33 ornithogenic and physical or mechanical weathering (Simas et al., 2008). The literature bears

34 little support for chemical weathering as an important soil forming process in maritime

35 Antarctica. Ornithogenic soils (i.e. soils with properties produced by avian activities) have been

36 described in several locations in the South Shetland Islands, on the Antarctic Peninsula, and at

37 several maritime locations along continental Antarctica (Michel et al., 2006; Simas et al., 2006;

38 Simas et al., 2007; Tatur, 2002). Phosphatization is an ornithogenic soil forming process that

39 produces a unique suite of phosphate minerals that is indicative of zones of active or relict

40 manuring by seabirds (mainly penguins). Phosphatization occurs when phosphorus rich guano,

41 mostly from penguins, interacts with water and soils. Fresh guano has a neutral $\mathrm{pH}$ and initial

42 stages of degradation enrich the surface of penguin rookeries with urates, ammonium, chitin,

43 struvite $\left(\left[\mathrm{NH}_{4}\right] \mathrm{MgPO}_{4} \cdot 6 \mathrm{H}_{2} \mathrm{O}\right)$ and apatite $\left(\mathrm{Ca}_{5}\left[\mathrm{PO}_{4}\right]_{3}[\mathrm{OH}, \mathrm{F}, \mathrm{Cl}]\right)$ (Myrcha and Tatur, 1991).

44 Volatilization and nitrification of ammonium ions and various hydrolysis reactions cause

45 phosphorus laden acidic solutions to percolate downwards, causing the following set of

46 phosphate minerals to precipitate: leucophosphite $\left(\mathrm{KFe}^{3+}{ }_{2}\left[\mathrm{PO}_{4}\right]_{2}[\mathrm{OH}] \cdot 2 \mathrm{H}_{2} \mathrm{O}\right)$; minyulite

$47\left(\mathrm{KAl}_{2}\left[\mathrm{PO}_{4}\right] 2[\mathrm{OH}]_{0.75} \mathrm{~F}_{0.25} \bullet 4 \mathrm{H}_{2} \mathrm{O}\right)$; metavariscite $\left(\mathrm{Al}\left[\mathrm{PO}_{4}\right] \cdot 2 \mathrm{H}_{2} \mathrm{O}\right)$; vashegyite

$48\left(\mathrm{Al}_{6}\left[\mathrm{PO}_{4}\right]_{5}[\mathrm{OH}]_{3} \cdot 22 \mathrm{H}_{2} \mathrm{O}\right) ;$ arctowskite $\left(\mathrm{Al}_{9}\left[\mathrm{PO}_{4}\right]_{8}[\mathrm{OH}]_{3} \cdot 27 \mathrm{H}_{2} \mathrm{O}\right)$; and vivanite

$49\left(\mathrm{Fe}_{3}^{2+}\left[\mathrm{PO}_{4}\right]_{2} \bullet 8 \mathrm{H}_{2} \mathrm{O}\right)($ Myrcha and Tatur, 1991; Pietr et al., 1983; Simas et al., 2007; Tatur, 1989).

50 The unique chemistry of ornithogenic soils and the identification of phosphate minerals in

51 abandoned rookeries hundreds of years old have prompted several researchers to suggest

52 "Ornithogenic" as an additional subgroup to Soil Taxonomy (Michel et al., 2006; Simas et al.,

53 2007). 
Soils at Hurd Peninsula, Livingston Island, in the South Shetland Island Archipelago, are

55 not only impacted by ornithogenic activity, but also receive some of the highest levels of tephra

56 deposition from volcanic activity at nearby Deception Island (Baker et al., 1975; Lee et al.,

57 2007). Tephra is a pyroclastic material dominated by amorphous glass-like materials that

58 weather to produce $\mathrm{Al}$ and $\mathrm{Si}$ rich minerals. The majority of tephra is andesitic origin and

59 weathers to produce an acidic environment favoring the formation of allophane and Al-organic

60 matter complexes typical of Andisols (Schaetzl and Anderson, 2005).

61 Previous soil investigations at Hurd Peninsula have been conducted by Moura et al.

62 (2012), Ganzert et al. (2011), and Navas et al. (2008). Navas et al. (2008) described and

63 analyzed the chemical propeties, physical properties, and mineralogy of 7 profiles from nearby

64 Byers Peninsula, the largest ice-free area in South Shetland Islands at $60 \mathrm{~km}^{2}$ ) and 4 profiles

65 from Hurd Peninsula to determine how soil properties varied with lithology. The study

66 concluded that bedrock lithology was more correlated with soil properties than physiographic

67 location or geomorphic unit and that physical weathering by freeze-thaw processes, as opposed

68 to chemical weathering, controlled soil formation. The goal of this study is to study soil-forming

69 processes on Hurd Peninsula, particularly in response to guano deposition from nearby penguin

70 colonies and volcanic ash deposition from the nearby Deception Island. Understanding how

71 penguin guano deposition is important because the alterations to the soil by guano mineralization

72 have several unique and poorly understood effects. Similarly, the mineral and nutrient

73 contributions from the weathering of volcanic ash on soils are virtually unknown in polar

74 regions, such as the Antarctic Peninsula.

76 Materials and Methods 
78 Hurd Peninsula, Livingston Island (62 39 'S $)$ is a $20 \mathrm{~km}^{2}$, north facing bedrock upland with a

79 maximum elevation of $400 \mathrm{~m}$ (Fig. 1). The peninsula receives approximately $800 \mathrm{~mm}$ of

80 precipitation per year and has a mean air average temperature (MAAT) between -1.5 to $-3.2^{\circ} \mathrm{C}$ at

$8115 \mathrm{~m}$ above sea level (a.s.1.), and approximately $-4.5^{\circ} \mathrm{C}$ at $275 \mathrm{~m}$ a.s.1. (recorded between 2000-

82 2006), with a range of $10^{\circ} \mathrm{C}$ to $-35^{\circ} \mathrm{C}$ (Ganzert et al., 2011; Hauck et al., 2007; Moura et al.,

83 2012). Air temperatures are generally positive from December to March and negative from April

84 through November, with very high humidities (80-90\%) encountered during the summer months

85 due to the influence of the polar front (Hauck et al., 2007).

Hurd Peninsula is comprised of Mesozoic sedimentary rocks of the Miers Bluff

87 Formation, which are mainly shales, siltstones, arkosic greywackes, and sandstones with some

88 interbedded conglomerates derived from volcanics and erosion of a volcanic island arc,

89 subsequently deposited as deep-water turbidites (Hobbs, 1968). The ice-free areas of Hurd

90 Peninsula are located along the coast while the center of the peninsula is covered by an ice dome

91 rising to $330 \mathrm{~m}$ a.s.1. The southern part of Hurd Peninsula is a rugged ice-free coast bordering

92 False Bay that has a maximum elevation of $400 \mathrm{~m}$ a.s.l. and terminates as coastal cliffs or very

93 steep bedrock slopes. The northerly side along South Bay has a more gentle topography with a

94 maximum height of $275 \mathrm{~m}$ a.s.l. and a marine eroded platform between 60 to $200 \mathrm{~m}$ a.s.l. that is

95 bisected by sloping glacially cut valleys filled with raised marine beaches.

96 The raised beaches on Hurd Peninsula have been classified as 1) lower beaches (1-3

97 terraces) under $2 \mathrm{~m}$ a.s.l. to the modern beach that have clean pebbles without lichens; 2 )

98 intermediate beaches (4-8 terraces) between 2.8 and $8 \mathrm{~m}$ a.s.l. with lichens; and 3) upper beaches

99 (1-4 terraces) between 12 and $18.6 \mathrm{~m}$ with lichens and Deschampsia antarctica (Lopez-Martinez 
100 et al., 1992). The radiocarbon dates of raised beaches at nearby Byers Peninsula suggests the

101 lower beaches formed less than 200 years BP; the intermediate beaches formed about 200 to

1022000 years BP; while the upper beaches formed between 2000 to 6000 years BP (Clapperton and

103 Sugden, 1988).

104 Above the raised beaches are early Pliocene to late Miocene marine eroded platforms 60-

$105200 \mathrm{~m}$ a.s.l. which are mostly sediment-free with the exception of a veneer of frost shattered

106 materials and the occasional rounded stone (Pallás et al., 1995). Regional tectonic uplift is likely

107 responsible for the marine eroded platforms which bear evidence of faulting, while the raised

108 beaches which show no evidence of fault deformation are likely the result of isostatic and

109 glacioeustatic changes. Geomorphic descriptions and maps of Hurd Peninsula can be found in

110 Lopez-Martinez et al. (1992) and Pallás et al. (1995).

111 Following the last glacial maximum, the ice sheet had retreated to at least the location of

112 the upper raised beaches by $6000 \mathrm{BP}$, but readvanced at least twice between 720-330 BP and

113 after 300 BP), depositing occasional recent moraines over raised beaches (Pallás et al., 1995).

114 The unconsolidated sediments that make up the soils on the peninsula include marine alluvium

115 on the raised beaches and glacial tills at Bulgarian Bay. Both sources are intermixed with frost

116 shattered rock of the Miers Bluff formation and volcanic ash derived from eruptions of nearby

117 Deception Island. Hurd Peninsula is particularly prone to tephra deposition from pyroclastic

118 eruptions of Deception Island volcanism, as shown by isopachs of a 1970 pyroclastic eruption of

119 Deception Island (Baker et al., 1975).

120 At least five known tephra layers, ranging in thickness from a few millimeters to $0.03 \mathrm{~m}$,

121 crop out of ice cliffs on the site. These five layers are correlated to pyroclastic eruptions that took

122 place between the early $19^{\text {th }}$ century and today (Pallás et al., 2001). In short, there is physical 
123 heterogeneity in soils across the peninsula, while the chemistry is relatively consistent and

124 dominantly a basaltic andesite composition (Baker et al., 1975).

125 Periglacial features are commonly found on the glacial till and include patterned ground,

126 rock glaciers, and stone banked lobes (i.e. sloping solifluction terraces). Permafrost is found

127 continuously above $30 \mathrm{~m}$ a.s.l., with active layer thicknesses decreasing with elevation; Mt.

128 Reina Sofia (275 m a.s.1.) has an active layer thickness less than $1 \mathrm{~m}$ deep (Hauck et al., 2007).

129 Cryoturbation features observed in soils by Navas et al. (2008) indicate that periglacial

130 conditions were more extensive in the recent past.

131 Metcheva and Zehtindjiev (2005) estimated the abundance of birds at Hurd Peninsula in

1322004 and found 90 nests of Pygoscelis papua (Gentoo Penguin) at Caleta Argentina (cove to the

133 west of Spanish Cove), 3,600 nests of P. antarctica (Chinstrap Penguin) at Miers Bluff and 30

134 nests of $P$. papua at Caleta Buena Nueva on the southern coast along False Bay. Occasional

135 occupation of penguins on the raised beaches is evidenced by common penguin excreta on

136 several of the current and raised beaches. Stercorarius antarcticus (Brown skua) is common in

137 areas adjacent to penguin colonies, especially above the large colony at Cape Hurd where they

138 are found in abundance.

139 The vegetation of Hurd Peninsula consists of lichens (mainly species of Himantormia,

140 Usnea and Umbilicaria), mosses (mainly Andreaea-rock moss and Drepanocladus-carpet moss)

141 and Deschampsia antarctica (Antarctic hair grass). Associations of rock mosses and lichens are

142 commonly encountered and can be found covering up to $90 \%$ of the oldest ice-free surfaces at all

143 elevations. Carpet mosses and D. antarctica occur both at lower elevations and on the raised

144 beaches; typical surface coverage on the raised beaches is 1-30\% (and up to 50\%). Algal mats of

145 Prasiola crispa that are commonly encountered near rookeries in the South Shetlands are rarely 
146 found at Hurd Peninsula.

148 Soil Sampling

149 A total of 19 soils were excavated to depths of up to $75 \mathrm{~cm}$ and 64 samples were collected during

150 the austral summer of 2011. Soils were collected from the following areas: Bulgarian Bay,

151 Spanish Cove, Miers Bluff and Mt. Riena Sophia. The pedon locations were selected to represent

152 the different geomorphic surfaces that occur on Hurd Peninsula as well as to evaluate soil

153 characteristics of a sequence of raised beaches. This is a judgment-based sampling strategy

154 typically used to collect observational data for soil landscapes where little previous research has

155 been conducted (Dijkerman, 1974). The soils were examined by hand-dug pits and described

156 according to Soil Taxonomy (Soil Survey Staff, 2010). The symbol "D” was used to describe

157 surface stone layers. Frozen soil materials are identified by the subscript "f" which if described

158 late in the Antarctic summer is likely synonymous with permanently frozen ground. Site and soil

159 classifications schemes (e.g. soil depth class) were determined according to the Soil Survey

160 Manual (Soil Survey Staff, 1993).

161

162 Soil Analysis

163 All soil samples were air dried prior to shipment to the laboratory for further analyses. The soil

164 samples were shipped to the laboratory in plastic bags. Upon arrival the soils were passed

165 through a $2 \mathrm{~mm}$ sieve, and the percentage of coarse fragments $>2 \mathrm{~mm}$ was recorded. Soil $\mathrm{pH}$ was

166 performed on a 1:1 soil to distilled water solution and a $1: 2$ soil to $0.01 \mathrm{M} \mathrm{CaCl}_{2}$ solution; and

167 electrical conductivity from a 1:2 soil to distilled water solution. Carbonates have been shown to

168 be almost entirely absent from the soils of Hurd Peninsula (Navas et al., 2008); their presence 
was tested by application of dilute 1M HCL acid to air-dried soils. Particle size distribution was

170 determined by laser-light diffraction on a Coulter LS230 laser according to the method of

171 Arriaga et al. (2006). Total carbon and nitrogen were tested by combustion on a Flash EA 1112

$17216 \mathrm{CN}$ Automatic Elemental Analyzer (Thermo Finnigan, Milan, Italy). Soils with a non-

173 effervescent reaction class were assumed to have total carbon approximately equal to organic

174 carbon. Total phosphorus, potassium, calcium, magnesium, iron, aluminum, and sodium were

175 determined by microwave digestion with $\mathrm{HCl}$ and $\mathrm{H}_{2} \mathrm{SO}_{4}$ and detection by ICP-OES (Maguire

176 and Heckendorn, 2011). Total iron-oxides were determined by dithionite-citrate extraction

177 according to the method of Holmgren (1967) with detection by ICP-OES.

178 In order to determine the presence of tephra in Hurd Peninsula soils, 10 fine grained

179 samples were examined using electron beam microscopy and microanalytical techniques with the

180 University of Wisconsin-Madison Department of Geoscience's Hitachi S3400 scanning electron

181 microscope (SEM) and CAMECA SX-51 electron probe microanalyzer (EPMA). Samples were

182 cast in epoxy in one-inch diameter rings, wet polished using progressly finer SiC papers, with a

183 final 0.35 micron diamond polish. They were then coated with $\sim 200 \AA$ of carbon to allow high

184 vacuum (no charging) in the SEM and EPMA.

185 The electron beam instruments provided three techniques: backscatter electron (BSE)

186 imaging, semi-quantitative energy dispersive spectroscopy (EDS), and quantitative, standards-

187 based wavelength dispersive spectroscopy (WDS). Similarly, six soil samples from the nearby

188 Deception Island, which contains an active volcano, were also examined for possible source

189 matches. These techniques examined soil samples for the presence of volcanic glass containing

190 crystals and vesicles that are generally associated with volcanic ash (Fisher and Schmincke,

191 1984). Once the presence of tephra was confirmed using SEM and BSE imaging assisted by 
192 EDS, and target grains chosen, the exact chemical composition of the glass in the identified

193 tephra was determined by EPMA-WDS. These glass compositions - both the Herd Peninsula and

194 the Deception Island ones -- can then be compared to published analyses of volcanic glass

195 sampled throughout the Antarctic (Kraus et al., 2012).

197 Results

198 Pedon Properties

199 Soils on Spanish Cove classify as Gelorthents at the lower elevations (< $8 \mathrm{~m}$ a.s.l.) and

200 Humigelepts at higher elevations (12-28 $\mathrm{m}$ a.s.1.). The pedons at Spanish Cove formed on a

201 toposequence of raised beaches with little periglacial alteration. Raised beaches were excavated

202 on terraces $4,5,6,8,12,13,18$, and $28 \mathrm{~m}$ a.s.l. (Table 1). For the purposes of this paper the 4-8

203 m raised beaches will be considered Lower Spanish Cove (LSC) and 12-28 m, Upper Spanish

204 Cove (USC). The soils on the raised beaches formed in rounded to subrounded marine sediments

205 intermixed with volcanic tephra. The $28 \mathrm{~m}$ raised beach is above the maximum elevation of

206 contemporary raised beaches described in the literature for the South Shetland Islands. It is

207 unclear if these are indeed contemporary raised beaches or represent one of the older marine

208 platforms that have been described on Livingston Island attaining heights of $143 \mathrm{~m}$ (John and

209 Sugden, 1971). The 4, 5, and $6 \mathrm{~m}$ raised beaches were the only ones to have a significant

210 accumulation of vegetation; the $4 \mathrm{~m}$ raised beach was dominated by nearly $50 \% \mathrm{D}$. antarctica

211 while the 5 and $6 \mathrm{~m}$ raised beaches were dominated by lichens. Coincidently, the 4, 5, and $6 \mathrm{~m}$

212 raised beaches were also the only with visible penguin excreta deposits on the surface. A

213 scattering $(<5 \%)$ of mosses appeared on the $12 \mathrm{~m}$ and higher raised beaches. The pedon

214 described at Mt. Reina Sophia (L19) was a Typic Haploturbel that formed in mixed till and frost- 
215 shattered rock that has formed non-sorted circles. Permafrost was detected between $0.9 \mathrm{~m}$ and

$2161.0 \mathrm{~m}$ (Hauck et al., 2007), supporting classification as Gelisol.

217 The pedons above Bulgarian Beach (BB) formed in till intermixed with frost-shattered

218 rock and tephra. The geomorphic features ranged from glacial to periglacial; raised beaches do

219 not occur in this area. The formation of stone-banked lobes is very common in the area.

220 Vegetation is sporadic with pockets of dense lichen or moss cover in an otherwise unvegetated

221 landscape. Bird activity is low presumably due to the lack of easy shore access in the absence of

222 raised beaches.

223 The Miers Bluff (MB) pedons formed on raised beaches that are also slightly above the

224 maximum elevation of raised beaches previously described in the South Shetland Islands. The

225 site is immediately adjacent to a $>200 \mathrm{~m}$ long rock glacier. The site has several nesting pairs of

226 Skuas that prey on a large chinstrap penguin rookery $(>3,000$ nests) located on the current beach

227 below. An association of D. antarctica, lichens and mosses covers up to $15 \%$ of the ground

228 surface.

229

230 Presence of Tephra

231 The demonstrated presence of tephra in soils of Hurd Peninsula indicates the contribution of

232 volcanic ash on soil development on Livingston Island. Vesicular volcanic glass associated with

233 gas-rich magma eruptions and aerial dispersal was found to be common in the soils of the Hurd

234 Peninsula (Fig. 2). Within the volcanic glass were vesicles created when dissolved gasses

235 exsolved due to the pressure drop during eruption. In association with the vesicles were FeTi-

236 oxide crystals which nucleated during eruption and were frozen together when the glass was

237 quenched. Most tephra samples were basaltic to andesitic in composition $\left(\mathrm{SiO}_{2} \sim 50-54 \%\right)$, 
238 which is a composition strikingly similar to the tephras analyzed from Deception Island. A point

239 count of volcanic fragments (based on presence of vesicles or glassy texture) conducted on 400

240 Hurd Peninsula samples determined that $73-92 \%$ of the fragments had extrusive volcanic origins.

241 Using EPMA we examined the glass in 43 tephra fragments from Hurd Peninsula and 15

242 fragments from Deception Island to determine the major and minor element oxides present in the

243 soil samples. Oxides examined included $\mathrm{SiO}_{2}, \mathrm{Na}_{2} \mathrm{O}, \mathrm{MgO}, \mathrm{Al}_{2} \mathrm{O}_{3}, \mathrm{P}_{2} \mathrm{O}_{6}, \mathrm{~K}_{2} \mathrm{O}, \mathrm{CaO}, \mathrm{FeO}, \mathrm{MnO}$

244 and $\mathrm{TiO}_{2} . \mathrm{SiO}_{2}$ was used as the common comparison variable (Lowe et al., 2014) (Fig. 3). There

245 was a good correlation for several oxides, especially $\mathrm{MgO}, \mathrm{K}_{2} \mathrm{O}$ and $\mathrm{CaO}$, and many outlier

246 samples found on Hurd Peninsula were also detected from Deception Island samples.

248 Soil Properties

249 Mean, median and standard deviation of the major soil nutrients for all the sites examined at 250 Hurd Peninsula were: total-carbon $(0.451 \%, 0.303 \%, 0.446)$; total-nitrogen $(0.080 \%, 0.063 \%$, 251 0.046); and total-phosphorus $(0.178 \%, 0.046 \%, 0.046)$ (Table 2). The average $\mathrm{pH}$ and EC were 2526.6 (range of 4.6-8.2) and $29.3 \mathrm{mS} \mathrm{m}^{-1}$ (range of 10-115). The textures were mainly coarse sands 253 with average sand, silt, and clay quantities of $82.9 \%, 11.6 \%$, and $5.6 \%$, respectively, while the > $2542 \mathrm{~mm}$ coarse fragments averaged $49.1 \%$.

255 The toposequence of raised beaches at Spanish Cove show differentiation with increasing 256 elevation. Rubification and horizonation of the Upper Spanish Cove (USC) raised beaches 257 increases with elevation (L09, L16, L17 and L18) starting at the $12 \mathrm{~m}$ a.s.1. (Fig. 4). Paralleling 258 these changes is the development of an approximately $0.3 \mathrm{~m}$ fine layered mantle overlying 259 coarser materials. The Lower Spanish Cove (LSC) raised beaches (L05-08) lack the finer 260 textured mantle and have significantly less silt and fine sand than the USC raised beaches (Table 
261 3). Similar to the USC sites, the raised beaches at Miers Bluff (MB) also display increases in 262 rubification, horizonation, and fine-textured material accumulations. In general, the LSC raised 263 beaches were coarser in both the fine earth and coarse fragment fraction than the other soils. 264 Total carbon and nitrogen are similar for both the USC (0.84 and $0.12 \%$, respectively) 265 and MB (0.70 and $0.12 \%$, respectively) raised beaches and are significantly higher than the LSC 266 (0.22 and $0.05 \%$ respectively) raised beaches or the glacially derived Bulgarian Bay (BB) soils 267 (0.16 and $0.05 \%$, respectively). Total-phosphorus on the MB soils were an order of magnitude 268 greater than total-phosphorus measured on the USC soils. Total-P for the USC and LSC raised 269 beaches and the glacial soils at BB were approximately $0.05 \%$ while the MB raised beaches 270 averaged nearly $1 \%$. Total-phosphorus was greater than $1 \%$ in the lower horizons of L10 (23 m $271 \mathrm{MB}$ raised beach) and reached 2.68\% in the BC horizon of L12 (26 m MB raised beach). Total272 calcium increased in $\mathrm{L} 10$ from $0.36 \%$ in the A horizon to $0.76 \%$ in the $2 \mathrm{Bw}$ and then decreased 273 to approximately $0.20 \%$ in the lowest horizons. In the BC horizon of L12 total-calcium was $2742.52 \%$, a nearly stoichiometric increase with total-phosphorus in the same horizon which 275 strongly indicates the presence of apatite minerals. Total-calcium between the BB soils and the 276 USC soils was not significantly different, but total-calcium was significantly lower on the LSC 277 soils. Total-magnesium was not significantly different among all sites, except the MB raised 278 beaches where it was found at half the concentrations (Table 3). Total-potassium for MB on the 279 other hand was found at concentrations more than two times higher than the other sites and 280 reached $0.34 \%$ in the $\mathrm{BC}$ horizon of $\mathrm{L} 12$.

281 The rubification of the subsoils in the USC and MB raised beaches was accompanied by 282 an approximately 30\% increase in the (citrate-dithionite extracted) iron and 50\% increase in 283 (citrate-dithionite extracted) aluminum compared to the LSC raised beaches. In addition to a 
284 general increase in total iron and aluminum for the USC and MB soils, a clear "bulge" in oxide-

285 iron and -aluminum is also evident in the subsoils above the $12 \mathrm{~m}$ raised beach as shown in Fig.

2865 for the Spanish Cove raised beaches. Data from the oxalate extraction (data not shown) gave

287 statistically similar results to the citrate-dithionite extraction, presumably due to the non-

288 crystalline nature of iron oxides in these soils (Schwertmann, 1973).

289 The $\mathrm{pH}$ values increased from 5.87 on the LSC raised beaches to 6.73 on the USC raised

290 beaches. The glacial soils at BB were also significantly higher than the LSC soil while the MB

291 raised beaches were slightly higher than the LSC raised beaches but not significantly so (Table

$2923)$.

293

\section{Discussion}

295 Previous researchers have stated that the major mechanism of weathering on the Antarctic

296 Peninsula in the absence of birds is mechanical breakdown (Hauck et al., 2008). However, the

297 clear developmental age trends observed at the soils of Hurd Peninsula indicate that chemical

298 weathering is occurring. In the oldest, most elevated raised beaches (USC and MB), the subsoil

299 shows rubification and the formation of Bw horizons. In the USC and MB raised beaches, there

300 is an increase in metals (total iron and aluminum), and in base cations (calcium, magnesium, and

301 potassium), relative to both the younger raised beaches at LSC, and the glacially derived soils at

302 BB (Table 3). In addition, the bulge in the data showing total oxide iron and aluminum extracted

303 by citrate dithionite suggests translocation of iron and aluminum into the subsoil (Fig. 5).

304

305

Mechanisms of Chemical Weathering

306 Soils at Hurd Peninsula are subject to both tephra and guano deposition. Chemical weathering is 
308 enhanced ion complexation in the presence of oxalic acid from uric acid decomposition, (ii)

309 phosphate promoted dissolution, and (iii) rapid weathering of tephra.

\section{(i) Oxalic acid promoted dissolution}

312 Nearly $50 \%$ of bird excrement is composed of nitrogenous compounds (Pietr et al., 1983), of

313 which approximately $70 \%$ is uric acid (Hutchinson, 1950). Uric acid rapidly converts to oxalic

314 acid or oxalate in terrestrial ecosystems (Lindeboom, 1984). Oxalate promotes dissolution of

315 silicate minerals at oxalate solutions greater than 90 ppm (Barman et al., 1992; Drever and

316 Stillings, 1997; Stillings et al., 1996). Typically, concentrations of oxalate in soils are less than

31790 ppm; however Roser et al. (2004) observed oxalic acid concentrations in soils under an active

318 penguin rookery soils at Windmill Islands, Antarctica, of more than 2,000 ppm oxalic acid. The

319 low temperatures of Hurd Peninsula soils are unlikely to inhibit oxalate enhanced dissolution as

320 oxalate has been shown to promote weathering in the extremely low temperatures of the

321 Antarctic Dry Valleys (Johnston and Vestal, 1993). The mechanism behind enhanced oxalate

322 dissolution is uncertain, specifically whether oxalic acid impacts dissolution through kinetic or

323 thermodynamic affects. Oxalic acid may impact the kinetics of dissolution by complexation

324 reactions that take place at the surface whereby oxalic acid binds directly with surface ions to

325 promote dissolution. Oxalic acid may change mineral dynamics by lowering solution $\mathrm{pH}$, thereby

326 enabling proton-attack in low-pH conditions $(<4)$. Alternatively, oxalic acid may alter the

327 stability of a mineral phase through complexation of ions in solution (particularly aluminum),

328 acting to alter saturation state with respect to the primary phase, thereby enhancing dissolution

329 relative to precipitation (Drever and Stillings, 1997). The older uplifted beaches (USC and MB) 
330 have had a longer period of time to be nested by penguins, allowing for oxalic acids to interact

331 with, dissolve and transport iron and aluminum in mineral soils.

(ii) Phosphate promoted dissolution

334 Crystalline phosphates are common to subsurface soils in Antarctica that have received heavy

335 inputs of guano, exceeding total phosphorus levels of $4 \%$ under penguin rookeries. The

336 dissolution of silicates and precipitation of minerals such as Palmerite $\left(\mathrm{HK}_{2} \mathrm{Al}_{2}\left(\mathrm{PO}_{4}\right)_{3} \cdot 7 \mathrm{H}_{2} 0\right)$ has

337 been shown to occur under laboratory conditions (Haseman et al., 1950). The experiments of

338 Haseman et al. (1950) showed that dissolution of primary clay minerals in the presence of

339 phosphate-solutions resulted in reprecipitation of phosphates in mineral phases such as

340 Palmerite, Barrondite, Variscite, and Strengite with mobilization of iron and aluminum to the

341 leachate. However, they found the rate of this process was only significant at temperatures

342 exceeding $49^{\circ} \mathrm{C}$ and at $\mathrm{pH}$ conditions less than 5. Thus, the ability of phosphate to induce

343 chemical weathering, although experimental possible, is unlikely in the climate and pH settings

344 observed in Hurd Peninsula soils. Furthermore, while there is a significant increase in

345 phosphorus in the soils found in the USC verses the LSC raised beaches, the increase barely

346 exceeds the average abundance of phosphorus in the earth upper crust (Taylor and Mclennan,

347 1995).

(iii) Rapid weathering of tephra

350 Tephra is added to the soils at Hurd Peninsula from nearby Deception Island, which erupts

351 frequently enough that observable accumulations of sand-sized material occurs. Tephra from

352 Deception Island is basaltic andesite and composed of scoriaceous glass and phenocrysts of 
353 plagioclase microlites; detailed chemical composition of the tephra from Hurd Peninsula can be 354 found in Pallás et al. (2001).

355 The glassy nature of tephra results in its rapid weathering in the soil environment with a 356 half-life of less than 10,000 years (Dahlgren et al., 1999). White (1983), observed that species

357 such as sodium, potassium and aluminum within glassy tephra are easily diffused away from the 358 glass surface and that it is likely that charge balance is maintained by the uptake of protons from 359 solution thereby raising $\mathrm{pH}$ during dissolution of fresh tephra. Extremely high levels of 360 extractable $\mathrm{Al}$ evident in the subsoils of the raised beaches above $12 \mathrm{~m}$ suggest that tephra 361 dissolution and translocation of weathering products has occurred. To investigate if tephra

362 deposition could possibly explain the high $\mathrm{pH}$ in the older and more developed soils, 10 grams of 363 tephra (as measured by Pallas et al., 2001) dissolved in $100 \mathrm{~L}$ of rainwater (solution chemistry

364 from Hem, 1985) was modeled using Geochemist's Workbench, and $\mathrm{pH}$ was predicted to

365 increase with reaction progress. The model results (Fig. 6) are in agreement with the assumption 366 of White (1983) that dissolution of tephra will increase $\mathrm{pH}$, at least while a fresh basaltic tephra 367 source remains.

\section{Ornithogenic soils at Miers Bluff}

370 Soil formation by phosphatization reactions are likely at the MB raised beaches. The

371 concentrations of total $\mathrm{P}$ found in ornithogenic soils typically ranges from $0.5-2.5 \%$ which is an

372 order of magnitude higher than in non-ornithogenic soils. The MB raised beaches have average

373 total-P concentrations greater than 1\%. Lighter horizon colors and finer textures observed in the

374 MB raised beaches are also indicative of ornithogenic soils (see L10 and L12 in Table 2).

375 The MB raised beaches however are in many respects similar to the USC raised beaches. 
Both have statistically similar carbon and nitrogen values and both have an increase in total

377 oxide iron and aluminum relative to the other soils as well as translocation of extractable iron

378 and aluminum into subsoil, and both have relatively similar elevations above sea level. The

379 major difference is a 10 fold increase in total-phosphorus in the MB raised beaches compared to

380 the USC raised beaches. The question is thus posed as to the source of the phosphorus, mainly is

381 the phosphorus derived from contemporary Skua guano or does the phosphorus represent a relict

382 ornithogenic deposit of penguins deposited before uplift of the beaches to the present elevation?

383 Normally, high phosphorus loadings are associated with high carbon and nitrogen in the

384 form of chitin and uric acids (Pietr et al., 1983). Increased vegetation at the USC raised beaches

385 also does not explain the similarities, as the MB raised beaches actually have more vegetative

386 ground cover. In addition, total magnesium which is usually associated with fresh guano derived

387 from seawater is significantly lower at MB than at USC. Calcium increases with depth until

$388 \mathrm{Ca}: \mathrm{PO}_{4}$ is $\sim 1: 1$, and is likely representative of a stoichiometric relationship from calcium

389 phosphate. The nearly stoichiometric relationship of calcium and phosphorus in the MB raised

390 beaches indicates that phosphatization reactions due to guano inputs have occurred. The loss of

391 carbon, nitrogen and magnesium and the increase in calcium suggest the MB raised beaches

392 contain relict ornithogenic soils. The production of noncrystalline materials released during rapid

393 weathering of tephra also has the ability fix very high levels of phosphorus and since

394 characterization of the phosphate minerals in these soils was not performed we are unable to say

395 with certainty which process predominates. However, Tatur (1989) observed that relict

396 ornithogenic soils and phosphate minerals were present hundreds to thousands of years later and

397 that under neutral to alkaline conditions apatite-like minerals were quite common. This

398 conclusion is contradictory to the findings of Emslie et al. (2010), who found it unlikely that 
399 older, relict rookeries of the P. papua or $P$. antarctica existed to any great extent since their

400 influx to the region appears to have been recent phenomenon (less than 1,000 yr BP).

\section{Conclusions}

403 Processes contributing to soil formation on Hurd Peninsula are identified and evaluated.

404 Chemical weathering is impacted by guano addition, and its effect was examined at a set of 405 comparable geomorphic landforms, two similar sets of raised beaches, one of which is directly

406 affected by ornithogenic conditions and another which is less so. Soils at Hurd Peninsula show

407 large amounts of intermixed tephra throughout soil profile, and the oldest soils at the top of the 408 raised beaches have accumulated a fine layered tephra mantle over time. Vegetation is not a 409 major contributor to soil formation at Hurd Peninsula, because it doesn't occur to large extent.

410 Tephra deposition is concluded to be the primary mechanism driving rubification and soil

411 formation, though guano deposition, which is spatially variable and temporally sporadic across

412 the site, also contributes to chemical weathering through the addition of oxalic acid.

413 Phosphatization reactions are likely only significant at the raised beaches on MB. Geochemical

414 modeling of tephra dissolution indicated that pore water $\mathrm{pH}$ increases in subsoil with dissolution.

415 Dissolution of silicates by phosphate is therefore likely not a major contributor due to

416 unfavorably low temperatures, unfavorably high $\mathrm{pH}$ conditions and low phosphorous levels.

417 Experiments measuring dissolution of tephra under varying oxalic acid concentration and $\mathrm{pH}$

418 over time would aid in confirming the conclusions suggested in this study. Characterization of

419 phosphate minerals and iron oxides in addition to additional geochemical modeling of mineral

420 dissolution reactions may further refine the proposed model for soil formation at the site. 


\section{Acknowledgments}

423 The National Science Foundation supported this research (NSF OPP-0943799). The Spanish and

424 Bulgarian Antarctic Programs provided logistical support in 2011. A.S. Haus assisted in the 425 geochemical modeling and reviews of this manuscript.

426 
References

428 Arriaga FJ., Lowery B, Mays MD. 2006. A Fast Method for Determing Soil Particle Size

Distribution Using A Laser Instrument. Soil Science 171: 663-674.

Baker PE, McReath MA, Harvey MR, Roobol MJ, Davies TG. 1975. The Geology of the South Shetland Islands: V. Volcanic Evolution of Deception Island. British Antarctic Survey Bulletin 78.

Beaudette DE, Roudier P, O’Geen AT. 2012. Algorithms for Quantitative Pedology: A Toolkit for Soil Scientists.

Clapperton CM, Sugden DE. 1988. Holocene Glacier Fluctuations in South America and Antarctica. Quaternary Science Reviews 7: 185-198.

Dahlgren RA, Ugolini FC, Casey WH. 1999. Field weathering rates of Mt. St. Helens tephra. Geochimica et Cosmochimica Acta 63: 587-598.

Dijkerman JC. 1974. Pedology as a Science: The Role of Data, Models and Theories in the Study of Natural Soil Systems. Geoderma 11: 73-93.

Drever JI, Stillings LL. 1997. The role of organic acids in mineral weathering. Colloids and Surfaces A: Physicochemical and Engineering Aspects 120: 167-181.

Emslie SD, Baumann K, Tuinen M. 2010. Late Holocene occupation of Gentoo Penguins (Pygoscelis papua) on Byers Peninsula, Livingston Island, Antarctica. Polar Biology 34(2): 283-290.

Fisher RV, Schmincke HU. 1984. Pyroclastic Rocks. Springer-Verlag, 472 pp.

Ganzert L, Lipski A, Hubberten H-W, Wagner D. 2011. The impact of different soil parameters on the community structure of dominant bacteria from nine different soils located on Livingston Island, South Shetland Archipelago, Antarctica. FEMS Microbiology Ecology 
76: $476-491$.

451 Haseman JF, Brown EH, Whitt CD. 1950. Some Reactions of Phosphate with Clays and Hydrous Oxides of Iron and Aluminum. Soil Science 70: 257-272.

Hauck C, Vieira G, Gruber S, Blanco J, Ramos, M. 2007. Geophysical identification of permafrost in Livingston Island, maritime Antarctica. Journal of Geophysical Research 112: F02S19.

Hem JD. 1985. Study and Interpretation of the Chemical Characteristics of Natural Water (Water Supply Paper 2254).

Hobbs GJ. 1968. The Geology of the South Shetland Islands IV. The Geology of Livingston Island. British Antarctic Survey Bulletin No 47.

Holmgren GGS. 1967. Rapid Citrate-Dithionite Extractable Iron Procedure. Soil Science Society of America Proceedings 31: 210-211.

Hutchinson GE. 1950. Survey of Contempory Knowledge of Biogeochemistry 3. The Biogeochemistry of Vertebrate Excretion. Bulletin of the American Museum of Natural History 96.

John BS, Sugden DE. 1971. Raised Marine Features and Phases of Glaciation in the South Shetland Islands. British Antarctic Survey Bulletin No 24.

Johnston C, Vestal J. 1993. Biogeochemistry of Oxalate in the Antarctic Cryptoendolithic Lichen-Dominated Community. Microbial Ecology 25: 305-319.

Kraus S, Kurbatov A, Yates M. 2012. Geochemical signatures of tephras from Quaterary Antarctic Peninsula volcaones, EarchChem Library. http://dx.doi.org/10.1594/IEDA/100052

Lee YI, Lim HS, Yoon HI, Tatur A. 2007. Characteristics of tephra in Holocene lake sediments 
on King George Island, West Antarctica: implications for deglaciation and paleoenvrionemnt. Quaternary Science Reviews 26: 3167-3178.

Lindeboom HJ. 1984. The Nitrogen Pathway in a Penguin Rookery. Ecology 65: 269-277.

476 Lopez-Martinez J, Martinez de Pison E, Arche A. 1992. Geomorphology of Hurd Peninsula, Livingston Island, South Shetland Islands. In Y. Yoshida, K. Kaminuma, \& K. Shiraishi (Eds.), Recent Progress in Antarctic Earth Science (pp. 751-756). Tokyo: TERRAPUB.

Lowe DJ, Pearce NJG, Jorgensen MA, Kuehn SC, Tryon CA, Hayward CL. 2014. Correlating tephras and cryptotephras using glass compositional analyses and statistical methods: a

Maguire RO, Heckendorn SE. 2011. Virgnia Tech Soil Testing Laboratory Procedures. Virginia review. Quaternary Science Reveiws, in press.

Metcheva R. Zehtindjiev P. 2005. Distribution and Abundance of Summer Birds Community Cooperative Extension 452-881. from South Bay (Livingston Island, South Shetland Islands, Antarctica). In B. Gruev, M. Nikolova, \& A. Donev (Eds.), Proceedings of the Balkan Scientific Conference of Biology (p. 453-458). Plovdiv (Bulgaria).

Michel R, Schaefer C, Dias LE, Simas F, Benites VM, Sá Mendonça E. 2006. Ornithogenic Gelisols (Cryosols) from Maritime Antarctica: Pedogenesis, Vegetation, and Carbon Studies. Soil Science Society of America Journal 70: 1370-1376.

Moura PA, Francelino MR, Schaefer CEGR, Simas FNB, Mendonça BAF. 2012. Distribution and characterization of soils and landform relationships in Byers Peninsula, Livingston Island, Maritime Antarctica. Geomorphology 155-156: 45-54.

Myrcha A, Tatur A. 1991. Ecological role of the current and abandoned penguin rookeries in the land enviornment of the maritime Antarctic. Polish Polar Resources, 12: 3-24. 
Navas A, López-martínez J, Casas J, Machín J, José J, Serrano E, Cuchi J, Mink S. 2008. Soil characteristics on varying lithological substrates in the South Shetland Islands, maritime Antarctica. Geoderma 144: 123 - 139.

Pallàs R, Smellie JL, Casas JM, Calvet J. 2001. Using tephrochronology to date temperate ice: correlation between ice tephras on Livingston Island and eruptive units on Deception Island volcano (South Shetland Islands, Antarctica). The Holocene 11: 149-160.

Pallàs R, Vllaplana JM, Sàbat F. 1995. Geomorphological and neotectonic features of Hurd Peninsula, Livingston Island, South Shetland Islands. Antarctic Science 7: 395-406.

Pietr SJ, Tatur A, Myrcha A. 1983. Mineralization of penguin excrements in the Admiralty Bay region (King George Island, South Shetland Islands, Antarctica). Polish Polar Research 4: $97-112$.

Roser DJ, Seppelt RD, Nordstrom O. 2004. Soluble carbohydrate and organic acid content of soils and associated microbiota from the Windmill Islands, Budd Coast, Antarctica. Antarctic Science 6(01): 53-59.

Schwertmann U. 1973. Use of Oxalate for Fe Extraction From Soils. Canadian Journal of Soil Science 53: 244-246.

Schaetzl R, Anderson S. 2005. in Soil Genesis and Geomorphology. Cambridge University Press, New York, NY. 207-210.

Simas FNB, Schaefer CEGR, Filho MR, Albuquerque-Filho MR, Francelino MR, Filho EIF, Costa LM. 2008. Genesis, properties and classification of Cryosols from Admiralty Bay, maritime Antarctica. Geoderma 144: 116 - 122.

Simas FNB, Schaefer CGR, Melo VF, Albuquerque-Filho MR, Michel, RFM, Pereira VV, ... Costa LM. 2007. Ornithogenic cryosols from Maritime Antarctica: Phosphatization as a 
soil forming process. Geoderma 138: 191-203.

520 Soil Survey Staff. 1993. Soil Survey Manual. Soil Conservation Service. U.S. Department of $521 \quad$ Agriculture Handbook 18.

522 Soil Survey Staff. 2010. Keys to Soil Taxonomy (11th ed.). USDA-Natural Resources

523 Conservation Service, Washington, DC.

524 Siillings LL, Drever JI, Brantley SL, Sun Y, Oxburgh R. 1996. Rates of feldspar dissolution at 525 pH 3 - 7 with 0 - 8 m M oxalic acid. Chemical Geology 132: 79-89.

526 Tatur A. 1989. Ornithogenic Soils of the Maritime Antarctic. Polish Polar Research 10: 481$527 \quad 532$.

528 Tatur A. 2002. Ornithogenic Ecosystems in the Maritime Antarctic- Formation, Development 529 and Disintegration. In L. Beyer \& M. Bolter (Eds.), Geoecology of Antarctic Ice-Free Coastal Landscapes (Vol. 154, pp. 161-184). Berlin: Springer.

531 Tatur A, Barczuk A. 1984. Phosphates of ornithogenic soils on the volcanic King George Island 532 (Maritime Antarctic). Polish Polar Research 5: 61-97.

533 Taylor SR, Mclennan SM. 1995. The Geochemical Evolution of the Continental Crust. Reviews $534 \quad$ of Geophysics 33: 241-265.

535 R Development Core Team. 2008. R: A language and environment for statistical computing. $R$ 536 Foundation for Statistical Computing, Vienna, Austria. ISBN 3-900051-07-0, URL http://www.R-project.org. Vienna, Austria. Retrieved from http://www.r-project.org

538 White AF. 1983. Surface chemistry and dissolution kinetics of glassy rocks at $25^{\circ} \mathrm{C}$.

$539 \quad$ Geochimica et Cosmochimica Acta 47: 805-815. 


\begin{tabular}{|c|c|c|c|c|c|c|c|c|c|}
\hline Profile & $\begin{array}{l}\text { Elev- } \\
\text { ation } \\
(m)\end{array}$ & $\begin{array}{l}\text { Slope } \\
(\%)\end{array}$ & $\begin{array}{l}\text { Soil } \\
\text { Depth } \\
(\mathrm{cm})\end{array}$ & $\begin{array}{l}\text { Plant } \\
\text { Cover } \\
(\%)\end{array}$ & $\begin{array}{l}\mathrm{C} \\
\left(\mathrm{kg} \mathrm{m}^{-2}\right)\end{array}$ & & $\mathrm{P}$ & Landform $^{\mathrm{a}}$ & $\begin{array}{l}\text { Taxonomic } \\
\text { Subgroup }\end{array}$ \\
\hline
\end{tabular}

$\begin{array}{llllllllll}\text { Spanish Cove } & & & & & & & & & \\ \text { L05 } & 4 & 1 & >50 & 50 & 0.50 & 0.13 & 0.11 & \mathrm{rb} & \text { Typic Gelorthents } \\ \text { L06 } & 5 & 0 & >50 & 30 & 0.34 & 0.14 & 0.09 & \mathrm{rb} & \text { Typic Gelorthents } \\ \text { L07 } & 6 & 0 & >40 & 30 & 0.35 & 0.10 & 0.07 & \mathrm{rb} & \text { Typic Gelorthents } \\ \text { L08 } & 8 & 1 & >45 & 5 & 0.35 & 0.08 & 0.09 & \mathrm{rb} & \text { Typic Gelorthents } \\ \text { L09 } & 12 & 0 & >50 & 10 & \text { NA } & \text { NA } & \text { NA } & \mathrm{rb} & \text { Typic Gelorthents } \\ \text { L17 } & 13 & 3 & >75 & 1 & 4.38 & 0.64 & 0.34 & \mathrm{rb} & \text { Typic Humigelepts } \\ \text { L16 } & 18 & 4 & >75 & 1 & 3.93 & 0.64 & 0.40 & \mathrm{rb} & \text { Typic Humigelepts } \\ \text { L18 } & 28 & 4 & >70 & <1 & 9.50 & 1.27 & 0.88 & \mathrm{rb} & \text { Typic Humigelepts } \\ & & & & & & & & & \\ \text { Mt Reina Sofia } & & & & & & & & & \\ \text { L19 } & 279 & 5 & 54 & 3 & 2.07 & 0.35 & 0.13 & \mathrm{nsc} & \text { Typic Haploturbels } \\ & & & & & & & & & \\ \text { Bulgarian Beach } \\ \text { L01 } & 137 & 9 & 38 & 50 & 0.70 & 0.22 & 0.12 & \mathrm{sbl} & \text { Typic Haplorthels } \\ \text { L02 } & 133 & 4 & 63 & 10 & 1.73 & 0.44 & 0.22 & \mathrm{cs} & \text { Lithic Gelorthents } \\ \text { L03 } & 35 & 7 & >60 & 50 & 0.31 & 0.28 & 0.17 & \mathrm{~m} & \text { Typic Gelorthents } \\ \text { L13 } & 115 & 47 & >54 & 0 & 0.35 & 0.15 & 0.06 & \mathrm{sbl} & \text { Typic Gelorthents } \\ \text { L14 } & 144 & 7 & 47 & 0 & 1.25 & 0.58 & 0.35 & \mathrm{nh} & \text { Typic Haplorthels } \\ \text { L15 } & 44 & 0 & >60 & 0 & 2.87 & 0.35 & 0.52 & \mathrm{~m} & \text { Typic Gelorthents }\end{array}$

Miers Bluff

\begin{tabular}{lccccccccc} 
L10 & 23 & 2 & 62 & 6 & 5.23 & 1.20 & 12.1 & $\mathrm{mp}$ & Typic Haploturbels \\
L12 & 26 & 0 & $>75$ & 10 & 4.19 & 0.69 & 6.65 & $\mathrm{mp}$ & Typic Gelorthents \\
\hline a cs: congelifractate surface; m: moraine; nh: nivation hollow; nsc: nonsorted circle; rb: raised beach; rg: \\
rock glacier; sbl: stone-banked lobe.
\end{tabular}




\begin{tabular}{|c|c|c|c|c|c|c|c|c|c|c|c|}
\hline \multirow[t]{2}{*}{ Horizon } & \multirow{2}{*}{$\begin{array}{l}\text { Depth } \\
(\mathrm{cm})\end{array}$} & \multirow{2}{*}{$\begin{array}{l}\text { Munsell color } \\
\text { (moist) }\end{array}$} & \multirow{2}{*}{$\begin{array}{l}\mathrm{pH} \\
\left(\mathrm{H}_{2} \mathrm{O}\right)\end{array}$} & \multirow{2}{*}{$\begin{array}{l}\mathrm{EC} \\
(\mu \mathrm{S} / \mathrm{cm})\end{array}$} & Total C & Total N & Total P & Clay & Silt & Sand & $>2 \mathrm{~mm}$ \\
\hline & & & & & \multicolumn{7}{|l|}{$(\%)$} \\
\hline \multicolumn{12}{|c|}{ L01 Bulgarian Beach } \\
\hline $\mathrm{D}$ & $0-1$ & $5 Y R 4 / 1$ & NA & NA & NA & NA & NA & NA & NA & NA & 97 \\
\hline $\mathrm{C} 1$ & $1-8$ & 5YR 2.5/1 & 6.51 & 20.9 & 0.184 & 0.053 & 0.026 & 3 & 5 & 92 & 60 \\
\hline $2 \mathrm{C} 2$ & $8-38$ & 10YR 3/2 & 6.74 & 16.6 & 0.165 & 0.053 & 0.031 & 5 & 11 & 84 & 65 \\
\hline $2 \mathrm{C} 3$ & $38-43$ & $10 Y R 3 / 2$ & 7.03 & 17.0 & 0.179 & 0.055 & 0.027 & 6 & 12 & 82 & 80 \\
\hline \multicolumn{12}{|c|}{ L02 Bulgarian Beach } \\
\hline $\mathrm{D}$ & $0-1$ & $10 Y R 3 / 2$ & NA & NA & NA & NA & NA & NA & NA & NA & 70 \\
\hline $\mathrm{C}$ & $1-16$ & $5 \mathrm{YR} 3 / 2$ & 6.56 & 18.1 & 0.138 & 0.053 & 0.022 & 3 & 6 & 91 & 5 \\
\hline $2 \mathrm{C} 1$ & $16-40$ & $10 Y R 4 / 3$ & 6.74 & 26.5 & 0.317 & 0.064 & 0.031 & 5 & 12 & 83 & 2 \\
\hline $2 \mathrm{C} 2$ & $40-63$ & $10 Y R 4 / 3$ & 6.9 & 17.0 & 0.146 & 0.049 & 0.029 & 4 & 25 & 71 & 45 \\
\hline $3 \mathrm{R}$ & $63+$ & NA & NA & NA & NA & NA & NA & NA & NA & NA & 0 \\
\hline \multicolumn{12}{|c|}{ L03 Bulgarian Beach } \\
\hline $\mathrm{D}$ & $0-1$ & $5 Y R$ 4/1 & NA & NA & NA & NA & NA & NA & NA & NA & 80 \\
\hline A & $1-9$ & 5YR 3/1 & 6.76 & 18.3 & 0.086 & 0.064 & 0.024 & 7 & 10 & 83 & 46 \\
\hline $\mathrm{C} 1$ & $9-20$ & $5 Y R 3 / 2$ & 7.26 & 12.6 & 0.095 & 0.062 & 0.025 & 3 & 7 & 90 & 56 \\
\hline $\mathrm{C} 2$ & $20-50$ & $5 Y R 3 / 2$ & 7.46 & 12.1 & 0.043 & 0.038 & NA & 2 & 3 & 95 & 66 \\
\hline $\mathrm{C} 3$ & $50-60$ & $5 Y R 3 / 2$ & 7.72 & 10.4 & 0.033 & 0.039 & 0.046 & 4 & 8 & 89 & 64 \\
\hline \multicolumn{12}{|c|}{ L05 Lower Spanish Cove } \\
\hline A & $0-5$ & 10YR 3/1 & 4.96 & 115.3 & 0.532 & 0.076 & 0.042 & 3 & 3 & 95 & 50 \\
\hline $\mathrm{C} 1$ & $5-36$ & $10 Y R 3 / 2$ & 6.36 & 38.4 & 0.168 & 0.047 & 0.050 & 1 & 1 & 99 & 82 \\
\hline $\mathrm{C} 2$ & $36-50$ & $10 \mathrm{YR} 2 / 2$ & 6.5 & 43.3 & 0.124 & 0.055 & 0.043 & 1 & 2 & 97 & 91 \\
\hline \multicolumn{12}{|c|}{ L06 Lower Spanish Cove } \\
\hline A & $0-3$ & $10 \mathrm{YR} 3 / 2$ & 5.05 & 80.1 & 0.335 & 0.062 & 0.036 & 7 & 6 & 87 & 82 \\
\hline $\mathrm{C} 1$ & $3-24$ & 10YR 3/1 & 6.14 & 27.9 & 0.185 & 0.046 & 0.036 & 5 & 4 & 91 & 83 \\
\hline $\mathrm{C} 2$ & $24-50$ & $10 \mathrm{YR} 2 / 2$ & 6.43 & 24.4 & 0.113 & 0.059 & 0.038 & 3 & 3 & 95 & 86 \\
\hline \multicolumn{12}{|c|}{ L07 Lower Spanish Cove } \\
\hline A & $0-3$ & 10YR 3/1 & 4.62 & 96.0 & 0.233 & 0.062 & 0.057 & 6 & 5 & 89 & 85 \\
\hline $\mathrm{C} 1$ & $3-20$ & 10YR 2/1 & 5.36 & 54.2 & 0.141 & 0.049 & NA & 4 & 4 & 92 & 85 \\
\hline $\mathrm{C} 2$ & $20-40$ & 10YR 2/1 & 6.01 & 27.6 & 0.153 & 0.040 & 0.038 & 3 & 3 & 94 & 87 \\
\hline \multicolumn{12}{|c|}{ L08 Lower Spanish Cove } \\
\hline A & $0-5$ & $10 Y R 3 / 2$ & 5.71 & 32.5 & 0.253 & 0.052 & 0.038 & 3 & 3 & 94 & 87 \\
\hline $\mathrm{C} 1$ & $5-29$ & $10 Y R 3 / 2$ & 6.61 & 16.3 & NA & NA & 0.042 & 3 & 5 & 92 & 88 \\
\hline $\mathrm{C} 2$ & $29-45$ & $10 Y R 3 / 3$ & 6.71 & 15.5 & 0.182 & 0.039 & 0.050 & 3 & 3 & 94 & 89 \\
\hline \multicolumn{12}{|c|}{ L09 Upper Spanish Cove } \\
\hline A & $0-13$ & $10 \mathrm{YR} 3 / 2$ & 6.22 & 19.4 & 0.407 & 0.061 & 0.058 & 3 & 7 & 90 & 53 \\
\hline $\mathrm{Bw}$ & $13-24$ & $10 Y R 3 / 4$ & 6.23 & 17.3 & NA & NA & 0.090 & 6 & 9 & 85 & 53 \\
\hline $2 \mathrm{BC}$ & $24-50$ & $10 \mathrm{YR} 3 / 3$ & 6.4 & 16.4 & NA & NA & 0.044 & 3 & 5 & 92 & 92 \\
\hline \multicolumn{12}{|c|}{ L10 Miers Bluff } \\
\hline A & $0-7$ & $10 Y R 3 / 3$ & 5.48 & 52.9 & 0.312 & 0.069 & 0.224 & 3 & 6 & 91 & 20 \\
\hline $2 \mathrm{Bw}$ & $7-18$ & $2.5 \mathrm{Y} 4 / 4$ & 6.56 & 19.0 & 1.111 & 0.196 & 1.619 & 17 & 26 & 57 & 5 \\
\hline $3 \mathrm{Ab}$ & $18-24$ & $10 Y R 3 / 3$ & 6.75 & 14.8 & NA & NA & 1.039 & 4 & 10 & 86 & 20 \\
\hline $3 \mathrm{C} 1$ & $24-51$ & $10 Y R 3 / 3$ & 6.21 & 40.5 & 0.346 & 0.087 & 0.961 & 6 & 44 & 50 & 2 \\
\hline
\end{tabular}




\begin{tabular}{|c|c|c|c|c|c|c|c|c|c|c|c|}
\hline $4 C 2$ & $51-62$ & 10YR 3/2 & 4.87 & 65.1 & NA & NA & 1.004 & 7 & 33 & 60 & 15 \\
\hline $4 C 3$ & 62 & NA & NA & NA & NA & NA & NA & NA & NA & NA & 0 \\
\hline \multicolumn{12}{|c|}{ L12 Miers Bluff } \\
\hline A & $0-8$ & $10 \mathrm{YR} 2 / 2$ & 5.57 & 44.2 & 0.444 & 0.073 & 0.086 & 3 & 6 & 90 & 35 \\
\hline $\mathrm{Bw}$ & $8-30$ & 10YR 3/2 & 6.86 & 13.6 & 1.156 & 0.129 & 0.306 & 9 & 19 & 73 & 40 \\
\hline $\mathrm{BC}$ & $30-60$ & 10YR 5/2 & 6.81 & 27.8 & 0.802 & 0.180 & 2.688 & 19 & 22 & 59 & 75 \\
\hline $2 \mathrm{C}$ & $60-75$ & NA & NA & NA & NA & NA & NA & NA & NA & NA & 0 \\
\hline \multicolumn{12}{|c|}{ L13 Bulgarian Beach } \\
\hline $\mathrm{C} 1$ & $0-16$ & 10YR 2/1 & 6.6 & 22.9 & NA & NA & 0.035 & 2 & 3 & 95 & 77 \\
\hline $\mathrm{C} 2$ & $16-34$ & 10YR 2/1 & 6.79 & 19.1 & 0.104 & 0.059 & 0.024 & 2 & 6 & 92 & 88 \\
\hline $\mathrm{C} 3$ & $34-54$ & $10 \mathrm{YR} 3 / 2$ & 6.82 & 18.5 & 0.177 & 0.068 & 0.029 & 2 & 6 & 92 & 86 \\
\hline \multicolumn{12}{|c|}{ L14 Bulgarian Beach } \\
\hline $\mathrm{C} 1$ & $0-33$ & $10 \mathrm{YR} 2 / 2$ & 7.01 & 18.5 & 0.052 & 0.051 & 0.013 & 2 & 3 & 95 & 9 \\
\hline $2 \mathrm{C} 2$ & $33-47$ & $10 \mathrm{YR} 4 / 3$ & 6.98 & 23.0 & 0.166 & 0.054 & 0.046 & 13 & 31 & 55 & 33 \\
\hline $2 \mathrm{C} 3$ & $47-50$ & NA & NA & NA & NA & NA & NA & NA & NA & NA & 0 \\
\hline $3 R$ & 50 & NA & NA & NA & NA & NA & NA & NA & NA & NA & 0 \\
\hline \multicolumn{12}{|c|}{ L15 Bulgarian Beach } \\
\hline $\mathrm{C} 1$ & $0-18$ & 10YR 5/1 & 8.02 & 99.3 & 0.185 & 0.019 & 0.048 & 9 & 16 & 76 & 32 \\
\hline $\mathrm{C} 2$ & $18-43$ & 10YR 5/1 & 8.23 & 77.9 & 0.353 & 0.038 & 0.051 & 9 & 16 & 74 & 32 \\
\hline $\mathrm{C} 3$ & $43-60$ & 10YR 5/1 & 8.22 & 73.4 & 0.283 & 0.038 & 0.052 & 10 & 17 & 73 & 29 \\
\hline \multicolumn{12}{|c|}{ L16 Upper Spanish Cove } \\
\hline A & $0-20$ & 10YR 2/1 & 6.79 & 16.1 & 0.281 & 0.062 & 0.035 & 2 & 4 & 94 & 5 \\
\hline Bw1 & $20-43$ & 7.5YR 3/2 & 6.88 & 15.4 & 0.574 & 0.089 & 0.050 & 4 & 8 & 88 & 3 \\
\hline 2Bw2 & $43-58$ & 10YR 3/2 & 6.85 & 19.5 & 0.872 & 0.112 & 0.052 & 9 & 26 & 65 & 77 \\
\hline $2 \mathrm{BC}$ & $58-75$ & $10 \mathrm{YR} 2 / 2$ & 6.98 & 22.3 & 0.577 & 0.077 & 0.078 & 4 & 9 & 87 & 82 \\
\hline \multicolumn{12}{|c|}{ L17 Upper Spanish Cove } \\
\hline A & $0-7$ & 10YR $2 / 2$ & 6.2 & 19.3 & 0.528 & 0.096 & 0.044 & 5 & 8 & 87 & 15 \\
\hline Bw1 & $7-25$ & 7.5YR 3/4 & 6.67 & 22.4 & 1.267 & 0.156 & 0.063 & 9 & 17 & 74 & 2 \\
\hline 2Bw2 & $25-33$ & $10 Y R 3 / 3$ & 6.82 & 14.1 & 1.055 & 0.145 & 0.079 & 9 & 21 & 70 & 82 \\
\hline $2 \mathrm{C}$ & $33-75$ & $10 \mathrm{YR} 3 / 2$ & 6.86 & 15.1 & 0.386 & 0.082 & 0.069 & 4 & 6 & 91 & 82 \\
\hline \multicolumn{12}{|c|}{ L18 Upper Spanish Cove } \\
\hline A & $0-8$ & 10YR 2/1 & 6.49 & 16.6 & 0.462 & 0.087 & 0.055 & 8 & 15 & 77 & 10 \\
\hline $\mathrm{A} / \mathrm{B}$ & $8-20$ & $10 \mathrm{YR} 3 / 2$ & 6.78 & 15.6 & 1.028 & 0.125 & 0.073 & 8 & 19 & 73 & 8 \\
\hline $\mathrm{B} / \mathrm{A}$ & $20-31$ & 7.5YR 3/4 & 7.07 & 13.5 & 1.009 & 0.131 & 0.090 & 7 & 14 & 79 & 5 \\
\hline $\mathrm{Bw}$ & $31-40$ & $7.5 \mathrm{YR} 3 / 4$ & 6.95 & 19.2 & 2.610 & 0.267 & 0.114 & 8 & 34 & 58 & 10 \\
\hline $2 \mathrm{BC}$ & $40-52$ & $10 \mathrm{YR} 3 / 3$ & 7.05 & 16.9 & 0.951 & 0.132 & 0.101 & 9 & 17 & 74 & 20 \\
\hline $2 \mathrm{C}$ & $52-70$ & $10 Y R 3 / 3$ & 7.15 & 17.1 & 0.654 & 0.104 & 0.093 & 8 & 14 & 79 & 45 \\
\hline \multicolumn{12}{|c|}{ L19 Mt Reina Sofia } \\
\hline A & $0-10$ & 10YR 2/1 & 6.2 & 25.4 & 0.294 & 0.072 & 0.023 & 4 & 8 & 88 & 42 \\
\hline $\mathrm{Bw}$ & $10-30$ & $10 Y R 3 / 4$ & 6.87 & 22.2 & 0.640 & 0.102 & 0.036 & 8 & 14 & 78 & 42 \\
\hline $\mathrm{BC}$ & $30-54$ & $10 Y R 3 / 3$ & 7.19 & 14.9 & 0.557 & 0.085 & 0.036 & 11 & 20 & 69 & 60 \\
\hline $\mathrm{C}$ & 54 & NA & NA & NA & NA & NA & NA & NA & NA & NA & 0 \\
\hline
\end{tabular}




\begin{tabular}{|l|c|l|l|l|l|}
\hline & Unit & $\begin{array}{c}\text { Spanish Cove } \\
(<\mathbf{1 2} \text { m a.s.l) }\end{array}$ & $\begin{array}{c}\text { Spanish Cove } \\
(\geq \mathbf{1 2} \text { m a.s.l. })\end{array}$ & $\begin{array}{c}\text { Bulgarian } \\
\text { Bay }\end{array}$ & $\begin{array}{c}\text { Miers } \\
\text { Bluff }\end{array}$ \\
\hline $\mathrm{pH}$ & & $5.87 \mathrm{~b}$ & $6.73 \mathrm{ac}$ & $7.13 \mathrm{a}$ & $6.14 \mathrm{bc}$ \\
\hline Total-C & $\%$ & $0.220 \mathrm{a}$ & $0.844 \mathrm{~b}$ & $0.159 \mathrm{a}$ & $0.695 \mathrm{~b}$ \\
\hline Total-N & $\%$ & $0.053 \mathrm{a}$ & $0.115 \mathrm{~b}$ & $0.050 \mathrm{a}$ & $0.122 \mathrm{~b}$ \\
\hline Total-P & $\%$ & $0.043 \mathrm{ab}$ & $0.070 \mathrm{~b}$ & $0.033 \mathrm{a}$ & 0.991 \\
\hline Total-Ca & $\%$ & $0.263 \mathrm{~b}$ & $0.445 \mathrm{a}$ & $0.568 \mathrm{a}$ & $0.663 \mathrm{ab}$ \\
\hline Total-Mg & $\%$ & $0.725 \mathrm{a}$ & $0.840 \mathrm{a}$ & $0.774 \mathrm{a}$ & 0.332 \\
\hline Total-K & $\%$ & $0.089 \mathrm{ab}$ & $0.058 \mathrm{a}$ & $0.072 \mathrm{a}$ & $0.201 \mathrm{~b}$ \\
\hline Total-Na & $\%$ & $0.125 \mathrm{a}$ & $0.156 \mathrm{a}$ & $0.158 \mathrm{a}$ & $0.162 \mathrm{a}$ \\
\hline Total-Al & $\%$ & $7825 \mathrm{a}$ & $16886 \mathrm{~b}$ & $12570 \mathrm{ab}$ & $10050 \mathrm{a}$ \\
\hline Total-Fe & $\%$ & $12904 \mathrm{a}$ & $18866 \mathrm{~b}$ & $17863 \mathrm{~b}$ & $15891 \mathrm{ab}$ \\
\hline Fine Clay & $\%$ & $0.83 \mathrm{a}$ & $1.7 \mathrm{a}$ & $1.2 \mathrm{a}$ & $2.1 \mathrm{a}$ \\
\hline Coarse Clay & $\%$ & $2.6 \mathrm{a}$ & $4.7 \mathrm{ab}$ & $3.7 \mathrm{ab}$ & $6.5 \mathrm{~b}$ \\
\hline Fine Silt & $\%$ & 2.6 & $8.3 \mathrm{a}$ & $6.6 \mathrm{a}$ & $10.1 \mathrm{a}$ \\
\hline Coarse Silt & $\%$ & 0.9 & $5.4 \mathrm{ac}$ & $4.2 \mathrm{a}$ & $10.6 \mathrm{c}$ \\
\hline Very Fine Sand & $\%$ & 0.8 & $4.5 \mathrm{ab}$ & $4 \mathrm{a}$ & $9.4 \mathrm{~b}$ \\
\hline Fine Sand & $\%$ & 4.7 & $11.3 \mathrm{a}$ & $9.8 \mathrm{a}$ & $12.7 \mathrm{a}$ \\
\hline Medium Sand & $\%$ & $16.8 \mathrm{a}$ & $18 \mathrm{a}$ & $14.7 \mathrm{a}$ & $12.3 \mathrm{a}$ \\
\hline Coarse Sand & $\%$ & 32 & $21.8 \mathrm{a}$ & $21.9 \mathrm{a}$ & $16.9 \mathrm{a}$ \\
\hline Very Coarse Sand & $\%$ & $38.8 \mathrm{a}$ & $24.4 \mathrm{bc}$ & $33.7 \mathrm{ac}$ & $19.8 \mathrm{~b}$ \\
\hline Coarse Frag. $(<2 \mathrm{~mm})$ & $\%$ & 82.9 & $37.9 \mathrm{a}$ & $48.8 \mathrm{a}$ & $21.2 \mathrm{a}$ \\
\hline $\begin{array}{l}\text { Means with same letters do not differ significantly among areas at } \mathrm{p}=0.05 . \text { Data analyses were } \\
\text { performed using Tukeys HSD procedure with R }(\mathrm{R}, 2008) .\end{array}$ \\
\hline
\end{tabular}




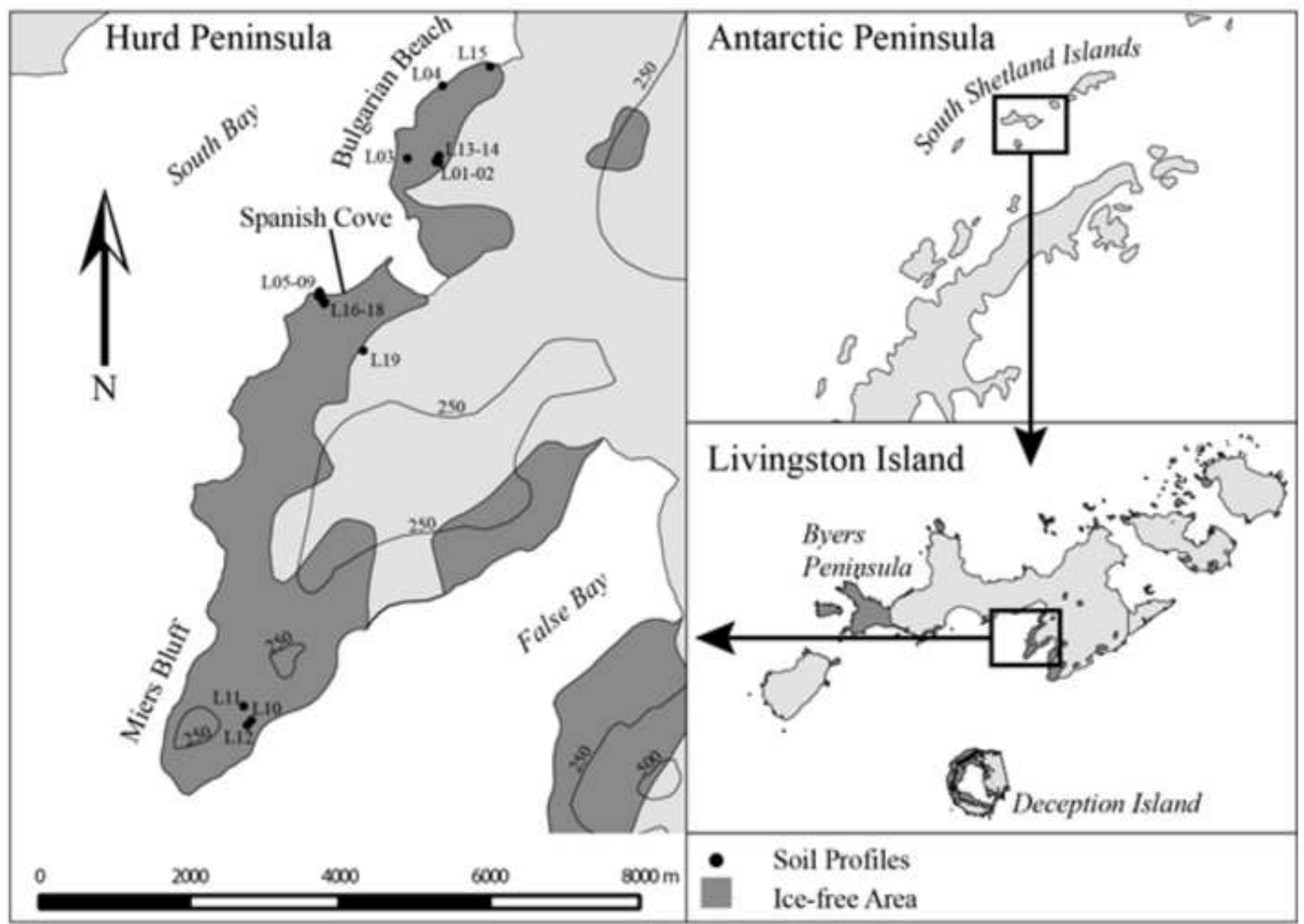




\section{Deception Island}

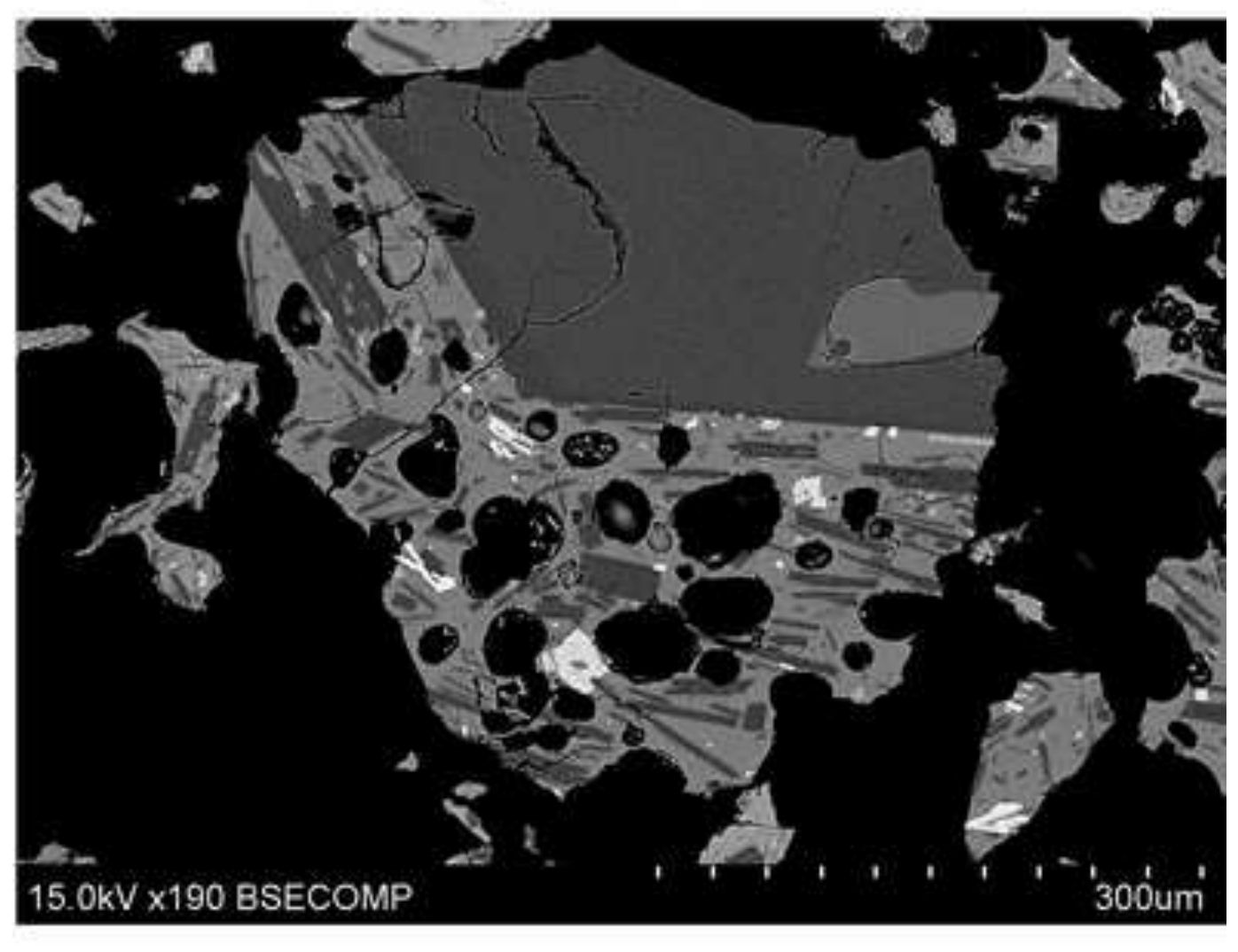

\section{Hurd Peninsula}
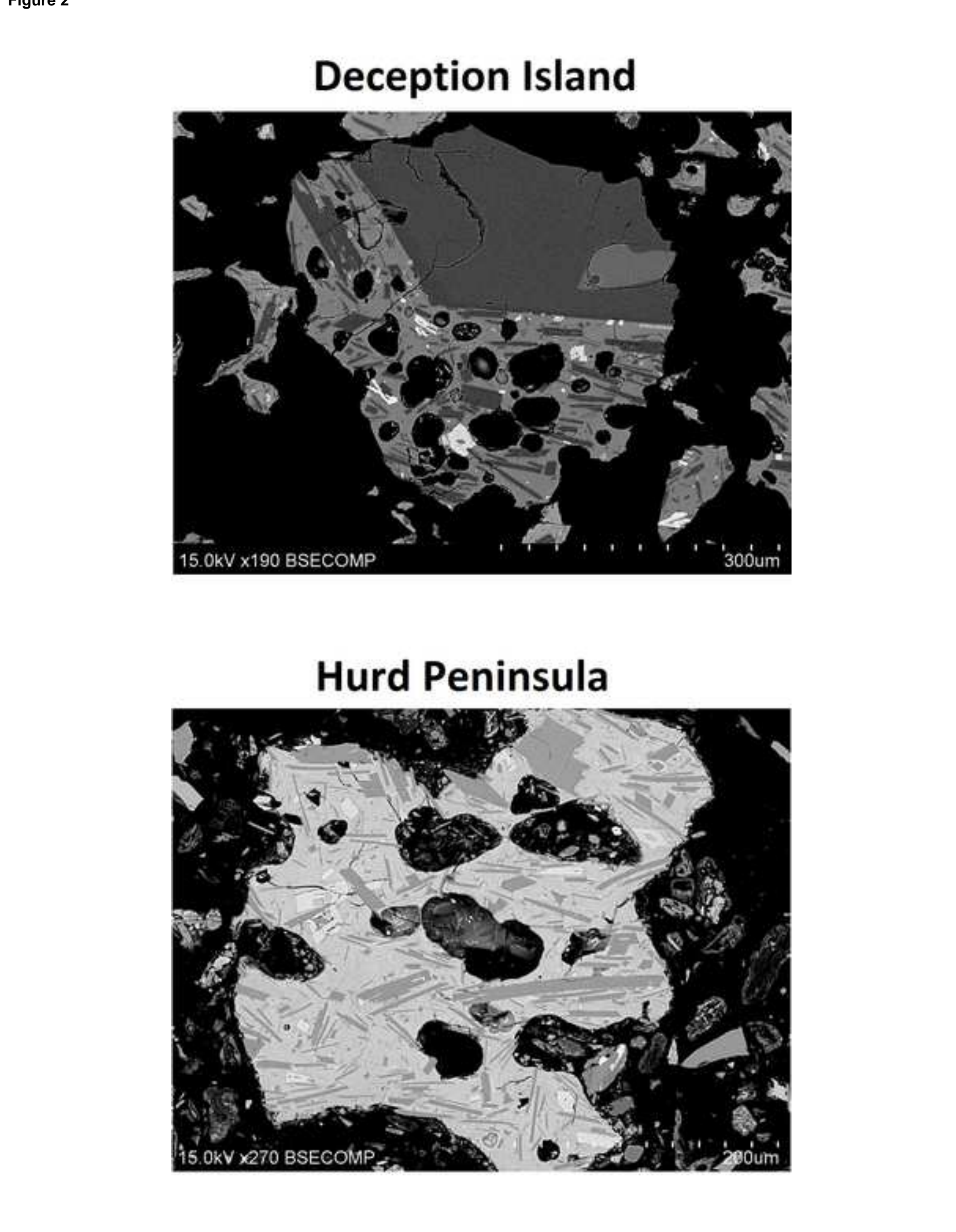

. 

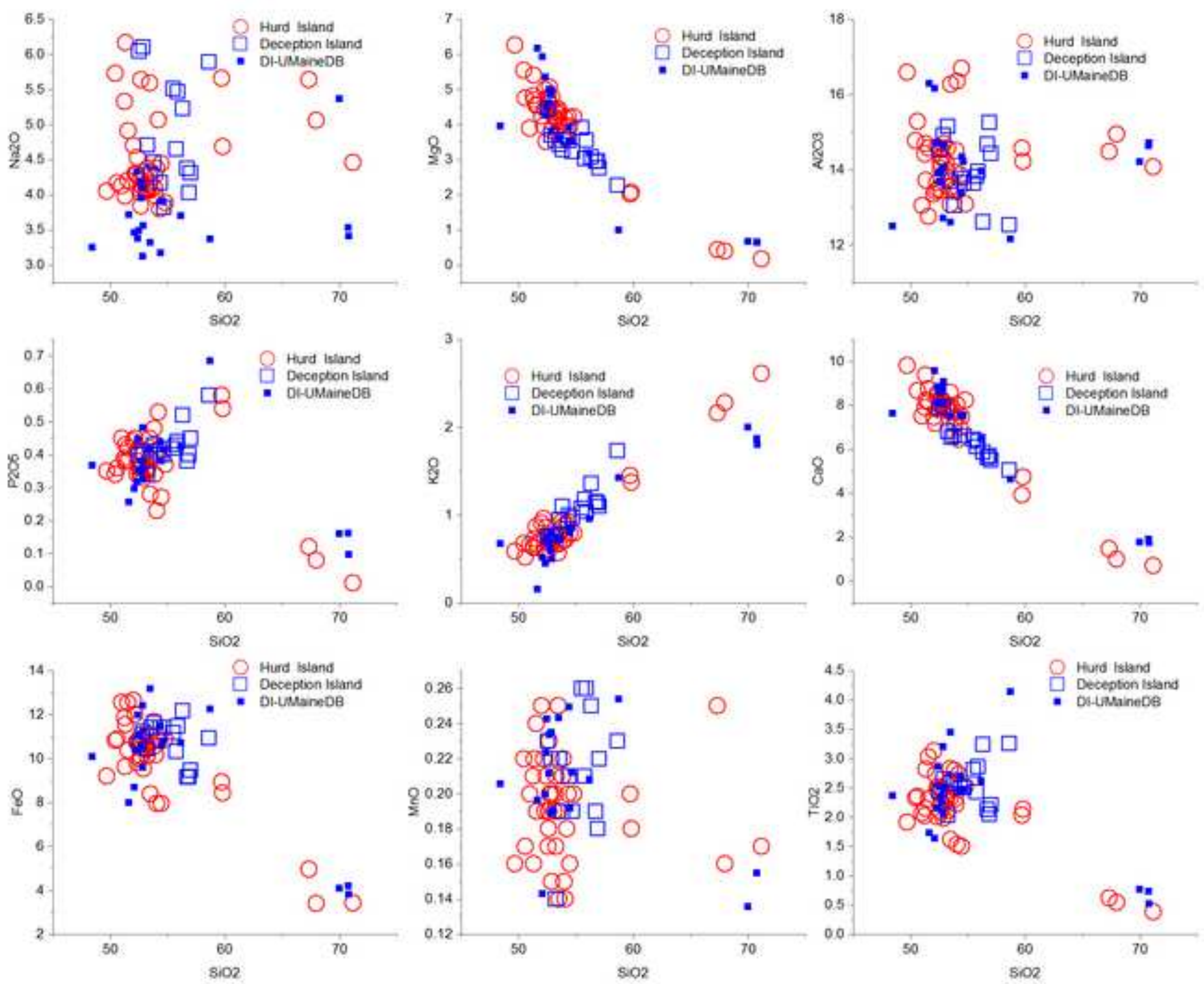
Soil Profiles of the Raised Beaches at Spanish Cove,

Hurd Peninsula, Livingston Island

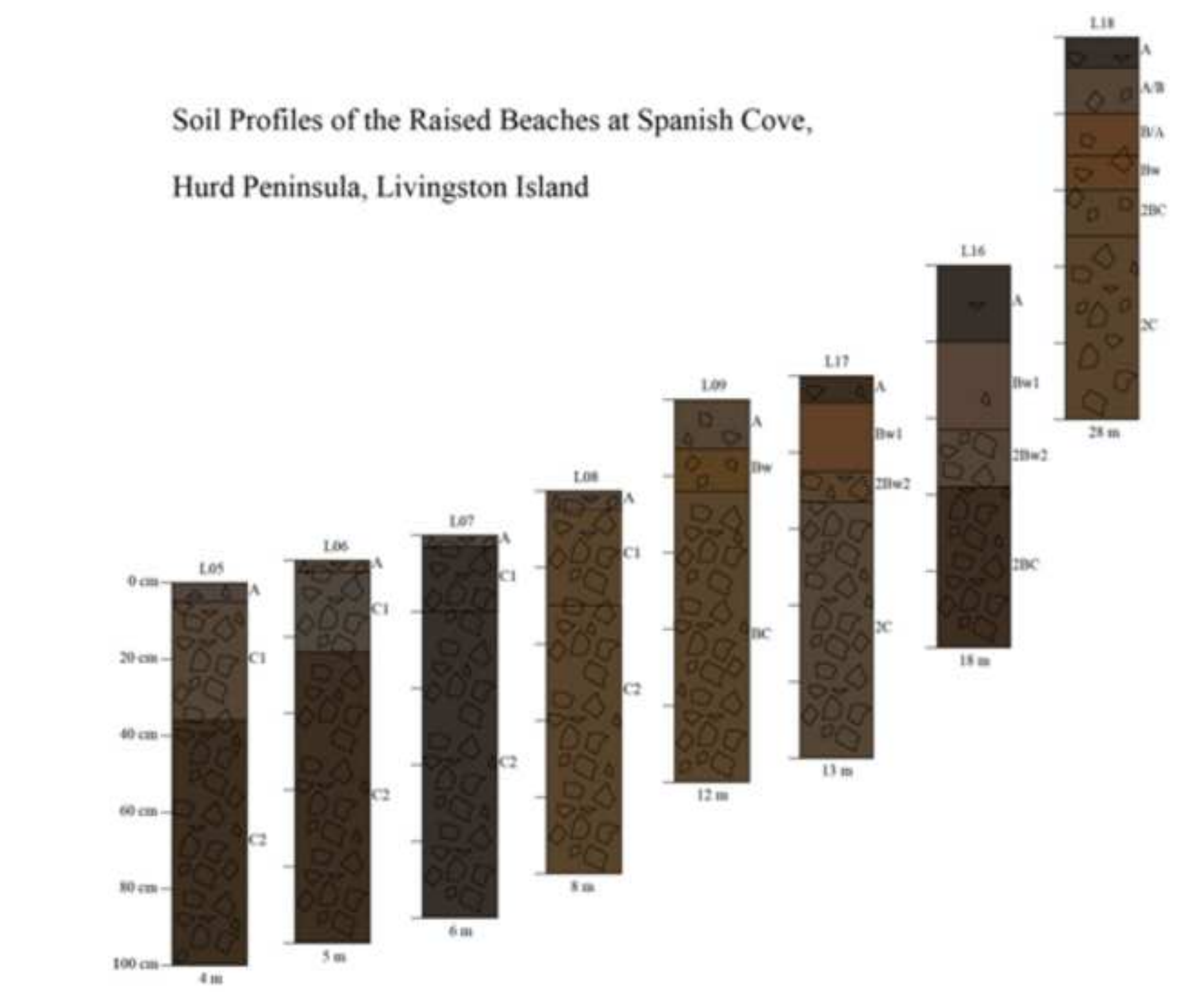

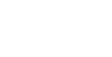




\section{Figure 5}

\section{Total Oxide $\mathrm{Fe}$ (mg ig}
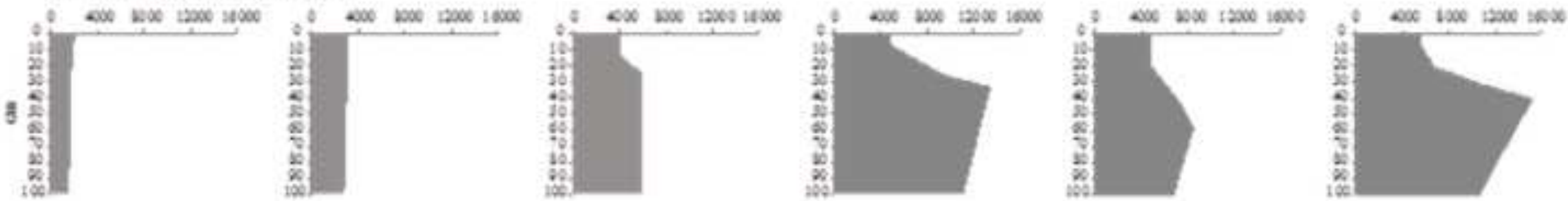

\section{Total Oxide Al (mg lo}
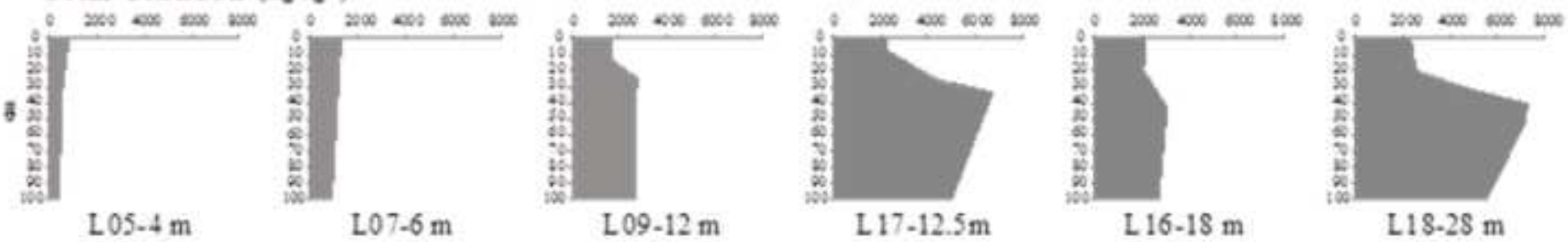


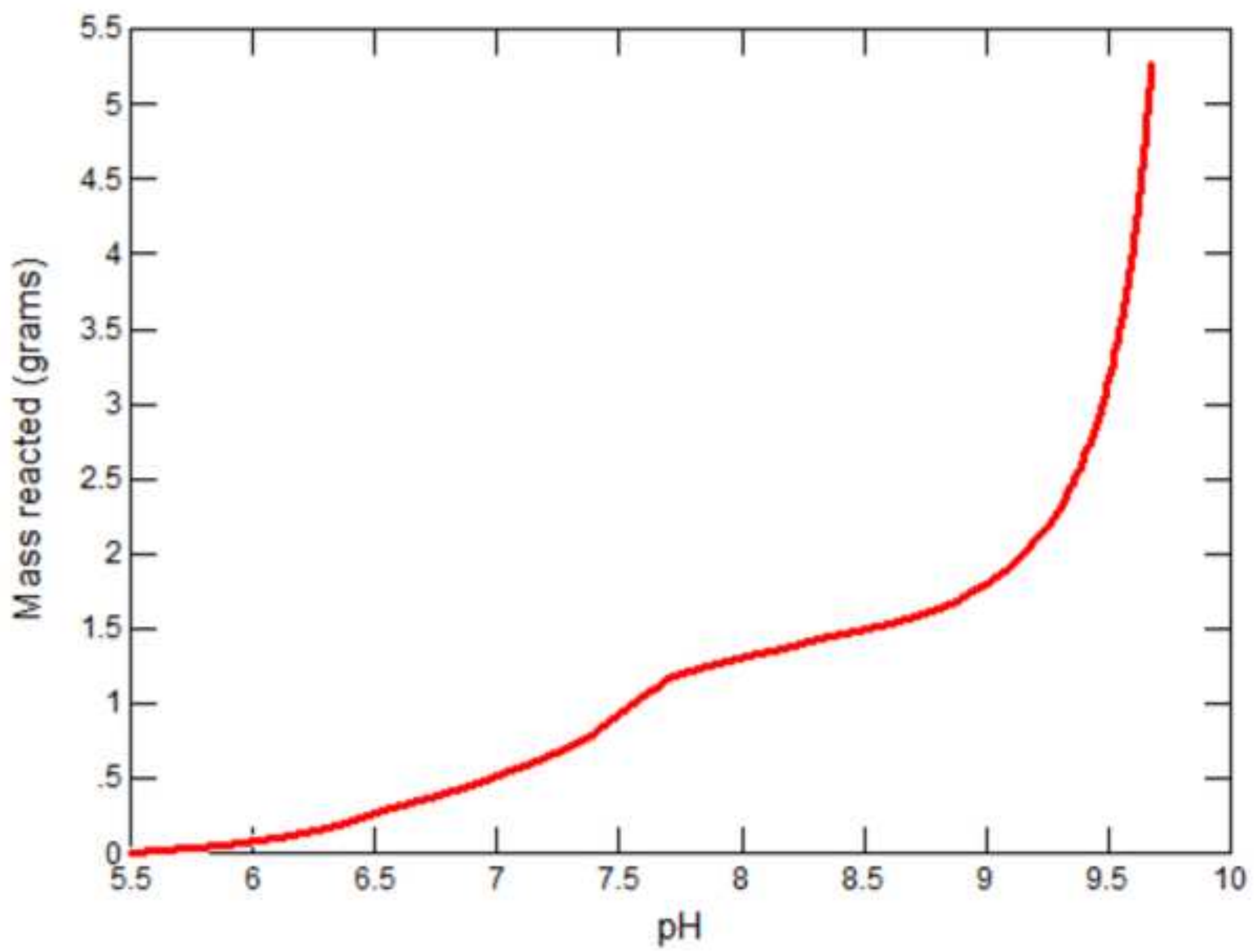




\section{Figure and Table Captions}

\section{Figures-}

Figure 1: Site map of location of Livingston Island (upper right), Hurd Peninsula (lower right) and the sampling sites on Hurd Peninsula.

Figure 2: Backscattered Electron image of tephra from Deception Island (top) and Hurd Peninsula (bottom). Black interstitial material indicates epoxy matrix. Light gray is volcanic glass while elongated darker gray crystals are plagioclase. White crystals are olivine with some FeTi-oxides. The very large dark gray plagioclase in the Deception Island sample is a phenocryst which grew in the magma chamber prior to eruption; all of the other small crystals nucleated during the eruption and were frozen together with the quenched volcanic glass. Black circular features within the tephra are voids from vapor bubbles as dissolved gases exsolved due to the pressure drop as the volcano erupted and the magma traveled up through the earth's crust. Fields of view: Deception Island 600 microns; Hurd Peninsula 250 microns.

Figure 3: Binary comparison of oxides percentages in tephra samples from Hurd Peninsula (Red circles) and Deception Island (Blue Squares). Included is EPMA oxide analysis of Deception Island glass samples from Kraus et al., 2012 (Blue dots, labeled DI-MaineDB).

Figure 4: Topochronosequence of soils on raised beaches at Spanish Cove. Artificial colors created with R using the aqp package (Beaudette, Roudier, \& O'Geen., 2012).

Figure 5: Citrate-dithionite extractable $\mathrm{Fe}$ and $\mathrm{Al}$ on a topochronosequence of raised beach at Spanish Bay.

Figure 6: Geochemical model demonstrating the theoretical dissolution of 5 grams of Hurd 
Peninsula tephra reacted with $100 \mathrm{~L}$ of rainwater.

\section{Tables-}

Table 1: Site and pedon characteristics for soils sampled during 2011 on Hurd Peninsula, Livingston Island.

Table 2: Analytical properties of pedons at Hurd Peninsula, Livingston Island.

Table 3: Means of the major nutrients and particle sizes by distinct areas at Hurd Peninsula. 